\title{
KEANEKARAGAMAN ARTHROPODA PADA PERTANAMAN TOMAT DENGAN SISTEM PERTANAMAN BERBEDA DI KABUPATEN TANGGAMUS, LAMPUNG
}

\author{
Herlinda Rama Danti, Yuyun Fitriana, Agus Muhammad Hariri, Purnomo \\ Jurusan Agroteknologi, Fakultas Pertanian, Universitas Lampung \\ Jl. Prof. Dr. Soemantri Brojonegoro No. 1 Bandar Lampung 35145 \\ Email : herlindaramadanti17februari@gmail.com
}

\begin{abstract}
ABSTRAK
Keberagaman organisme yang saling berinteraksi dalam suatu ekosistem menentukan stabilitas ekosistem tersebut. Penelitian ini bertujuan untuk mengetahui kemelimpahan dan keanekaragaman Arthropoda pada sistem pertanaman tomat monokultur dan polikultur di Pekon Gisting Permai, Kecamatan Gisting, Kabupaten Tanggamus, Lampung. Penelitian menggunakan metode purposive sampling atau ditentukan secara sengaja pada tiga blok monokultur serta tiga blok polikultur. Pertanaman polikultur terdiri dari tanaman tomat dan cabai. Setiap blok berukuran $20 \mathrm{~m}$ x $20 \mathrm{~m}$. Pengambilan sampel Arthropoda dengan menggunakan tiga perangkap sumuran yang diletakkan secara diagonal serta menggunakan lima tanaman sampel untuk pengamatan tajuk pada setiap blok pengamatan. Hasil penelitian menunjukkan seluruh Arthropoda yang ditemukan adalah 2.559 individu terdiri dari 1.371 individu pada pertanaman monokultur dan 1.188 individu pada pertanaman polikultur. Pada pertanaman monokultur ditemukan sembilan ordo dan 16 famili, sedangkan pada pertanaman polikultur ditemukan sembilan ordo dan 22 famili. Rata-rata nilai Indeks Keanekaragaman Shannon-Wiener, Kemerataan dan Kekayaan Jenis pada pertanaman polikultur lebih tinggi dari pada pertanaman monokultur.
\end{abstract}

Kata kunci : keanekaragaman, Arthropoda, monokultur, polikultur, tomat

\section{PENDAHULUAN}

Tomat (Solanum lycopersicum L.) merupakan salah satu sayuran yang banyak dikonsumsi oleh masyarakat di Indonesia. Tomat dapat dimanfaatkan sebagai bahan untuk membuat makanan seperti olahan masakan, saos atau dibuat jus.

Menurut Badan Pusat Statistik (2016), produksi tomat nasional selama 3 tahun terakhir mengalami penurunan. Produksi pada tahun 2013 sebesar 992.780 ton, tahun 2014 sebesar 915.987 ton, dan tahun 2015 sebesar 877.792 ton. Mustikawati, 2012 menyatakan bahwa salah satu faktor yang menyebabkan penurunan produksi tomat adalah adanya serangan organisme pengganggu tanaman yaitu hama dan penyakit.

Pada ekosistem pertanian dijumpai komunitas Arthropoda yang terdiri atas banyak jenis dan masingmasing jenis memperlihatkan sifat populasinya yang khas. Tidak semua jenis Arthropoda merupakan hama, namun dapat juga berperan sebagai predator, dekomposer, penyerbuk, parasitoid, dan parasit (Untung, 1996). Seperti juga yang diungkapkan oleh Hildrew \&
Townsend (1982) bahwa kelimpahan mangsa akan menarik minat predator untuk datang dan tinggal di tempat tersebut, kemudian diikuti dengan meningkatnya kemampuan predator dalam memangsa. Mangsa atau hama yang berbeda memungkinan tersedianya musuh alami yang beragam pada suatu ekosistem. Keberagaman organisme yang saling berinteraksi dalam suatu ekosistem menentukan stabilitas ekosistem tersebut. Semakin beragam organisme di dalam suatu ekosistem, maka akan semakin tinggi stabilitas pada ekosistem tersebut (Odum,1971 dalam Yudha, 2016; Krebs, 1985 dalam Yudha, 2016).

Salah satu komponen teknologi Pengendalian Hama Terpadu (PHT) yang dapat diterapkan untuk mengendalikan hama adalah pengendalian secara kultur teknik (pengelolaan tanah dan sistem tanam). Pertanaman secara tumpangsari dapat menurunkan serangan Organisme Pengganggu Tanaman (OPT) melalui cara mengurangi penyebaran karena adanya penghadang tanaman bukan inang dan salah satu spesies tanaman berfungsi sebagai perangkap atau penolak (Setiawati et al., 2005). Mulyani (2010) melaporkan 
bahwa ekosistem polikultur memiliki komposisi hama dan musuh alami yang paling seimbang sehingga ekosistem yang terbentuk lebih stabil dibanding dengan sistem tanam lain. Oleh karena itu, untuk mengetahui keberadaan komponen-komponen komunitas diperlukan suatu kajian mengenai keanekaragaman Arthropoda.

Tanggamus merupakan salah satu daerah penghasil sayuran di Provinsi Lampung. Salah satu sentra produksi sayuran tomat di daerah Tanggamus adalah di Kecamatan Gisting. Sampai saat ini, informasi tentang kemelimpahan dan keanekaragaman Arthropoda pada pertamanan tomat di Kabupaten Tanggamus masih sangat terbatas. Penelitian ini bertujuan untuk mengetahui kemelimpahan dan keanekaragaman Arthropoda pada pertanaman tomat monokultur dan polikultur di Pekon Gisting Permai, Kecamatan Gisting, Kabupaten Tanggamus, Lampung.

\section{METODE PENELITIAN}

Penelitian ini dilaksanakan pada lahan pertanaman tomat di Pekon Gisting Permai, Kecamatan Gisting, Kabupaten Tanggamus, Provinsi Lampung. Metode pemilihan lokasi penelitian adalah purposive sampling atau ditentukan secara sengaja. Proses identifikasi dan perhitungan populasi Arthropoda dilakukan di Laboratorium Hama Tumbuhan, Fakultas Pertanian, Universitas Lampung. Identifikasi dilakukan sampai pada tingkat takson famili menggunakan buku determinasi Lilies (1991) dan Boror et al. (1996). Penelitian ini dilaksanakan pada bulan Juli sampai dengan bulan September 2017.

Lahan penelitian terdiri dari tiga blok monokultur dan tiga blok polikultur, masing-masing ukuran blok sekitar $20 \mathrm{~m} \times 20 \mathrm{~m}$. Pada masing-masing blok dipasang tiga pitfall trap untuk diamati berbagai jenis Arthropoda pada permukaan tanah dan ditetapkan lima tanaman sampel untuk diamati berbagai jenis Arthropoda tajuk. Pengambilan sampel Arthropoda dilakukan pada pertanaman tomat sebanyak enam kali yaitu tiga kali sebelum tanaman berbunga ( 39 hst; 46 hst; dan 53 hst) serta tiga kali pada saat tanaman berbunga (60 hst; 67 hst; dan 74 hst) (Edi \& Julistia, 2010).

Variabel pengamatan dalam penelitian ini meliputi kemelimpahan dan keanekaragaman Arthropoda. Variabel kemelimpahan adalah jumlah individu, sedangkan variabel keanekaragaman meliputi jumlah ordo, famili, indeks keanekaragaman Shannon-Weiner $\left(H^{\prime}\right)$, Indeks Kemerataan (E), dan Kekayaan Jenis $\left(\mathrm{D}_{\mathrm{mg}}\right)$.

\section{Indeks Keanekaragaamn Shannon-Wiener (H')}

Rumus yang digunakan untuk menghitung Indeks Keanekaragaman Shannon-Wiener (H') adalah Magurran(1988) :

$$
\begin{gathered}
\mathrm{H}^{\prime}=-\sum \mathrm{p}_{\mathrm{i}} \ln \mathrm{p}_{\mathrm{i}} \\
\text { dengan } \mathrm{p}_{\mathrm{i}}=\sum \mathrm{n}_{\mathrm{i}} / \mathrm{N}
\end{gathered}
$$

Keterangan:

H' = Indeks Keanekaragaman Shannon-Weiner

$\mathrm{p}_{\mathrm{i}} \quad=$ Proporsi individu yang ditemukan pada

famili ke-i

$\mathrm{n}_{\mathrm{i}} \quad=$ Jumlah individu pada famili ke-i

$\mathrm{N}=$ Jumlah total individu

\section{Indeks Kemerataan $($ Evenness $=\mathrm{E})$}

Indeks kemerataan menunjukkan kemerataan setiap jenis dalam setiap komunitas yang dijumpai. Rumus untuk menghitung indeks kemerataan adalah Magurran (1988) :

$$
\begin{gathered}
\mathrm{E}=\mathrm{H}^{\prime} / \mathrm{H}^{\prime}{ }_{\text {max }} \\
\text { dengan } \mathrm{H}^{\prime}{ }_{\text {max }}=\ln \mathrm{S}
\end{gathered}
$$

Keterangan :

$\mathrm{E} \quad=$ Indeks kemerataan $(0-1)$

H' = Indeks Keanekaragaman Shannon-Wiener

$\ln \quad=$ logaritma natural

$\mathrm{S} \quad=$ Jumlah famili

\section{Indeks Kekayaan Jenis ( $\left.D_{m g}\right)$}

Rumus yang digunakan untuk menghitung indeks kekayaan jenis adalah Magurran (1988) :

Keterangan:

$$
\mathrm{D}_{\mathrm{mg}}=(\mathrm{S}-1) / \ln \mathrm{N}
$$

$\mathrm{D}_{\mathrm{mg}} \quad=$ Indeks Kekayaan Jenis Margalef

$\mathrm{S} \quad=$ Jumlah famili

$\mathrm{N}=$ Total individu dalam sampel

\section{HASIL DAN PEMBAHASAN}

Hasil pengamatan Arthropoda pada sistem pertanaman tomat monokultur dan polikultur di Kabupaten Tanggamus disajikan pada Tabel 1. Ordo Collembola memiliki proporsi tertinggi baik di blok-blok monokultur $(75,49 \%)$ maupun di blok-blok polikultur $(69,28 \%)$. Collembola yang berperan sebagai dekomposer memang merupakan Arthropoda yang paling banyak ditemukan dalam suatu agroekosistem (Samudra et al., 2013; Indahwati et al., 2012). 
Tabel 1. Ordo, famili, dan jumlah Arthropoda pada pertanaman tomat

\begin{tabular}{|c|c|c|c|c|c|c|c|}
\hline \multirow{2}{*}{ No } & \multirow{2}{*}{ Kelas/Ordo } & \multirow{2}{*}{ Famili } & \multirow{2}{*}{ Fungsi } & \multicolumn{4}{|c|}{ Jumlah Individu (ekor) } \\
\hline & & & & $M$ & $\%$ & $P$ & $\%$ \\
\hline \multirow[t]{24}{*}{1} & Insekta & & & & & & \\
\hline & Coleoptera & Carabidae & Predator & 5 & 0,365 & 3 & 0,253 \\
\hline & & Cicindelidae & Predator & - & - & 2 & 0,168 \\
\hline & & Coccinelidae & Predator & - & - & 4 & 0,337 \\
\hline & & Curculionidae & Herbivora & - & - & 2 & 0,168 \\
\hline & & Histeridae & Predator & 1 & 0,073 & - & - \\
\hline & & Nitidulidae & Herbivora & 3 & 0,219 & - & - \\
\hline & & Staphylinidae & Predator & 12 & 0,875 & 5 & 0,421 \\
\hline & Collembola & Hypogastruridae & Dekomposer & 1.035 & 75,49 & 823 & 69,28 \\
\hline & Dermaptera & Carcinophoridae & Predator & 43 & 3,136 & 54 & 4,545 \\
\hline & & Forficulidae & Predator & 31 & 2,261 & 23 & 1,936 \\
\hline & Diptera & Tephritidae & Herbivora & - & - & 8 & 0,673 \\
\hline & Hemiptera & Aleyrodidae & Herbivora & 9 & 0,656 & - & - \\
\hline & & Alydidae & Herbivora & - & - & 13 & 1,094 \\
\hline & & Reduviidae & Predator & - & - & 1 & 0,084 \\
\hline & & Pentatomidae & Herbivora & 2 & 0,146 & - & - \\
\hline & Hymenoptera & Formicidae & Predator & 109 & 7,95 & 103 & $\overline{8,67}$ \\
\hline & & Ichneumonidae & Parasitoid & 1 & 0,073 & - & - \\
\hline & Lepidoptera & Noctuidae & Herbivora & 14 & 1,021 & - & - \\
\hline & Orthoptera & Acrididae & Herbivora & - & - & 3 & 0,253 \\
\hline & & Blattidae & Herbivora & - & - & 1 & 0,084 \\
\hline & & Phasmatidae & Herbivora & - & - & 1 & 0,084 \\
\hline & & Gryllidae & Herbivora & 22 & 1,605 & 34 & 2,862 \\
\hline & & Gryllotalpidae & Herbivora & 10 & 0,729 & 17 & 1,431 \\
\hline \multirow[t]{8}{*}{2} & Arachnida & & & & & & \\
\hline & Araneae & Araneidae & Predator & - & - & 1 & $\overline{0,084}$ \\
\hline & & Linyphiidae & Predator & 3 & 0,219 & - & - \\
\hline & & Lycosidae & Predator & 71 & 5,179 & 78 & 6,566 \\
\hline & & Salticidae & Predator & - & - & 1 & 0,084 \\
\hline & & Tetragnathidae & Predator & - & - & 10 & 0,842 \\
\hline & & Oxyopidae & Predator & - & - & 1 & 0,084 \\
\hline & Total & & & 1.371 & & .188 & \\
\hline
\end{tabular}

Keterangan: $\quad \mathrm{M}=$ Sistem Pertanaman Tomat Monokultur

$\mathrm{P}=$ Sistem Pertanaman Tomat Polikultur

\section{Kemelimpahan Arthropoda}

Hasil pengamatan jumlah Arthropoda pada pertanaman tomat monokultur dan polikultur disajikan pada Gambar 1. Nilai Kemelimpahan Arthropoda pada pertanaman monokultur lebih tinggi (1.371) dari pada polikultur (1.188). Hal ini sangat dipengaruhi oleh tingginya jumlah Ordo Collembola yang ditemukan pada pertanaman monokultur. Pada lahan pertanaman monokultur banyak ditumbuhi gulma-gulma yang dapat memacu tingginya populasi Ordo Collembola karena banyaknya sumber bahan organik yang dibutuhkan oleh
Ordo Collembola tersebut. Indahwati et al. (2012) menyebutkan bahwa kemelimpahan Arthropoda pada setiap lahan ditentukan oleh dua faktor yaitu faktor dari dalam (intrinsik) yaitu kecenderungan Arthropoda untuk menyukai lingkungan dengan kondisi tertentu dan faktor luar (ekstrinsik) yang terdiri dari faktor biotik dan abiotik. Arthropoda akan melimpah jika kondisi lingkungannya mendukung, seperti suplai makanan, kandungan oksigen dan adanya tempat berlindung dari gangguan maupun predator. 


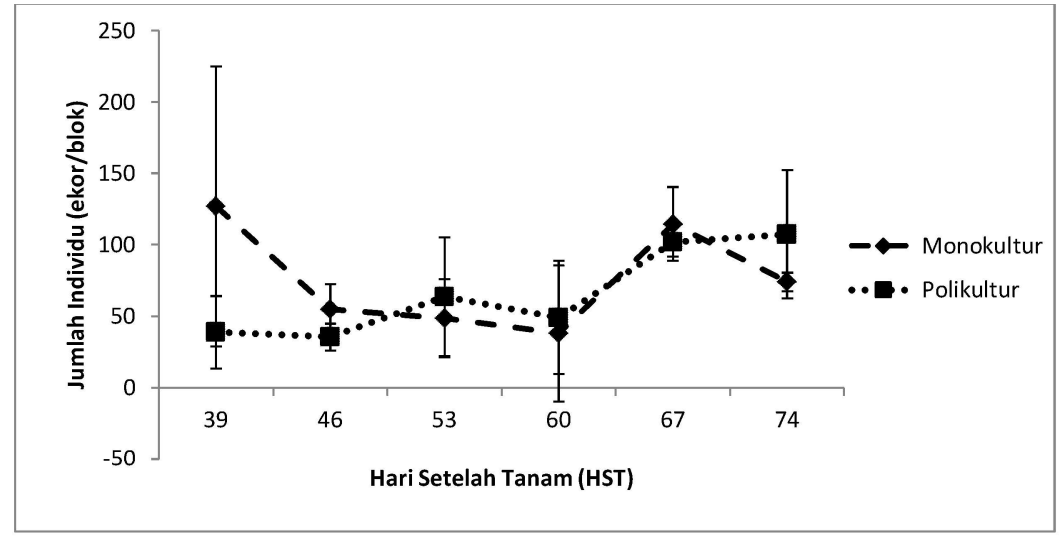

Gambar 1. Fluktuasi kemelimpahan Arthropoda pada pertanaman tomat

\section{Keanekaragaaman Arthropoda}

Fluktuasi indeks keanekaragaman Arthropoda pertanaman tomat monokultur dan polikultur disajikan pada Gambar 2. Tinggi rendahnya Indeks Keanekaragaman Shannon-Wiener (H') dipengaruhi oleh jumlah individu. Keanekaragaman akan rendah apabila dalam suatu komunitas terdapat suatu famili yang memiliki jumlah individu lebih banyak, berbeda bila dibandingkan dengan komunitas yang memiliki jumlah individu sedikit tetapi termasuk dalam beberapa famili maka keanekaragamannya akan tinggi (Sugiatno, 1994 dalam Yudha, 2016). Rata-rata Indeks Keanekaragaman Shannon-Wiener (H') pada pertanaman polikultur sejak 39 hst sampai 74 hst lebih tinggi yaitu 1,16 dibandingkan dengan pertanaman monokultur yaitu 1,01 . Walaupun jumlah total individu yang ditemukan di pertanaman polikultur lebih sedikit dibandingkan pada pertanaman monokultur, namun jumlah famili yang ditemukan pada pertanaman polikulturlebih banyak yaitu 22 famili, sedangkan pada pertanaman monokultur hanya 16 famili. Penanaman secara polikultur dapat menjadikan suatu ekosistem lebih stabil dibandingkan dengan penanaman secara monokultur. Hal ini dikarenakan penanaman secara polikultur memiliki indeks keanekaragaman yang lebih tinggi dan memiliki komposisi hama dan musuh alami yang lebih seimbang dibandingkan dengan penanaman secara monokultur (Mulyani, 2010). Yaherwandi (2009) melaporkan bahwa kekayaan jenis dan keanekaragaman pada ekosistem polikultur lebih tinggi dari pada monokultur. Nurmaisah (2016) menyatakan bahwa keanekaragaman jenis serangga pada lahan polikultur lebih tinggi dibandingkan dengan lahan monokultur tanaman terung belanda di Desa Dieng Kulon, Jawa Tengah.

\section{Kemerataan Arthropoda}

Indeks kemerataan (E) Arthropoda pada pertanaman tomat monokultur dan polikultur disajikan pada Gambar 3. Rata-rata Indeks Kemerataan Jenis (E) pada pertanaman polikultur sejak 39 hst sampai 74 hst lebih tinggi yaitu 0,62 dibandingkan dengan pertanaman monokultur yaitu 0,55 . Hal ini dikarenakan tingginya jumlah individu Ordo Collembola Famili Hypogastruridae yang mendominasi dalam suatu komunitas yang banyak ditemukan pada blok-blok

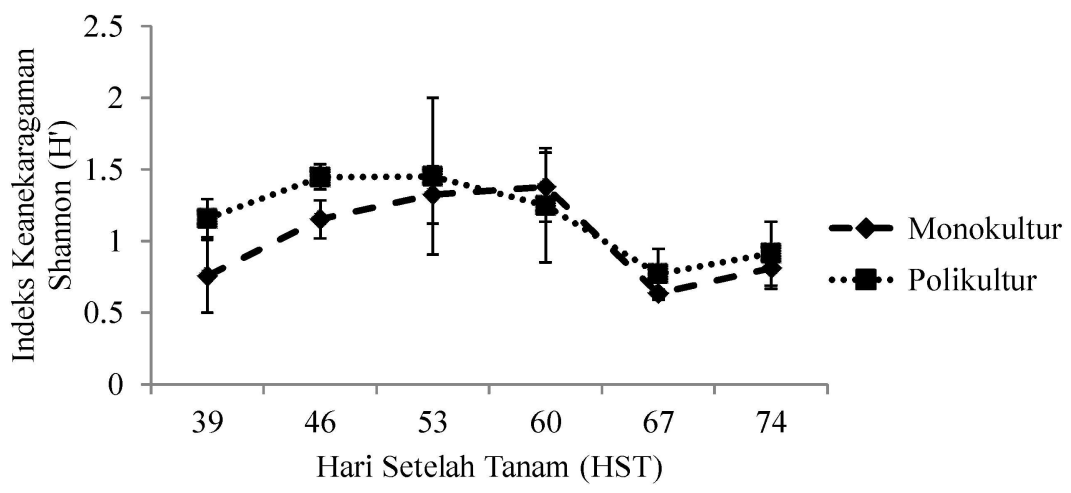

Gambar 2. Fluktuasi indeks keanekaragaman Shannon-Weiner (H') Arthropoda pada pertanaman tomat 


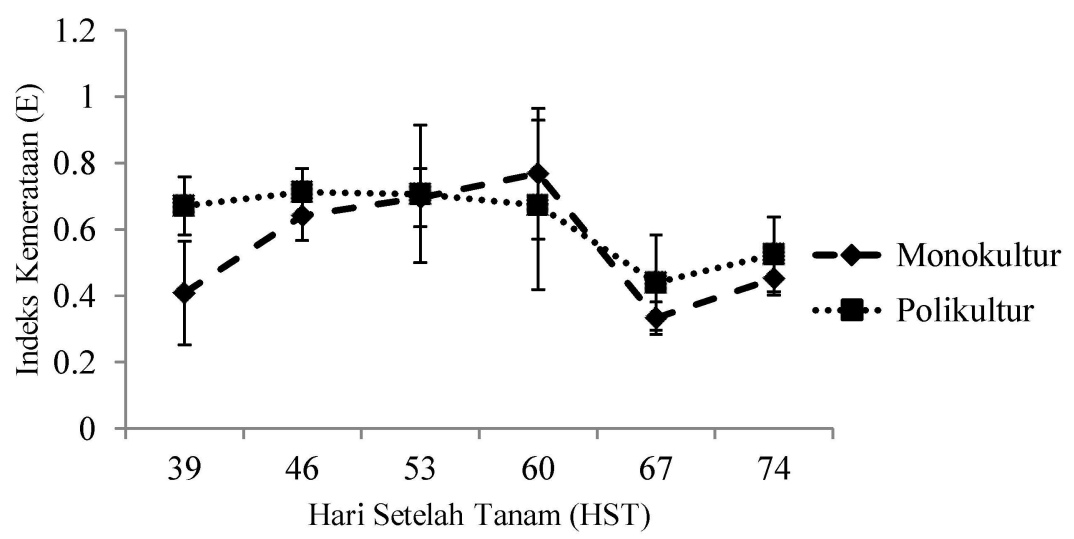

Gambar 3. Fluktuasi indeks kemerataan (E) Arthropoda pada pertanaman tomat

pertanaman monokultur. Semakin kecil nilai E, maka semakin besar jumlah suatu jenis Arthropoda yang mendominasi di komunitas tersebut (Oka, 1995). Pada penelitian Yaherwandi (2009) diketahui bahwa kemerataan spesies pada ekosistem sayuran monokultur lebih rendah dibandingkan pada ekosistem sayuran polikultur. Yaherwandi et al. (2007) menyatakan bahwa kemerataan spesies suatu ekosistem akan kecil bila kemelimpahan spesies pada ekosistem tersebut tidak merata atau dengan kata lain terdapat satu atau dua spesies yang sangat dominan.

\section{Kekayaan Jenis Arthropoda}

Indeks kekayaan jenis $\left(D_{m g}\right)$ Arthropoda pertanaman tomat monokultur dan polikultur disajikan pada Gambar 4. Rata-rata Nilai Indeks Kekayaan Jenis $\left(\mathrm{D}_{\mathrm{mg}}\right)$ pada pertanaman polikultur sejak 39 hst sampai 74 hst lebih tinggi yaitu 1,45 dibandingkan dengan pertanaman monokultur yaitu 1,37 . Hal ini dikarenakan pada pertanaman polikultur terdapat lebih banyak jenis
Arthropoda yang ditemukan dan tidak terdapat pada pertanaman monokultur. Famili-famili Arthropoda tersebut diantaranya adalah Cleridae, Coccinelidae, Reduviidae, Araneidae, Salticidae, Tetragnathidae, dan Oxyopidae yang semuanya berperan sebagai predator. Selain itu, juga ditemukan Curculionidae, Tephritidae, Alydidae, Acrididae, Blattidae, dan Phasmatidae yang berperan sebagai herbivora. Pada pertanaman tomat monokultur ditemukan 9 ordo dan 16 famili, sedangkan pada pertanaman tomat polikultur ditemukan 9 ordo 22 famili. Pada penelitian Yaherwandi (2009) diketahui bahwa kekayaan jenis pada ekosistem sayuran monokultur lebih rendah dibandingkan pada ekosistem sayuran polikultur. Yaherwandi et al.(2007) menyatakan bahwa kekayaan dan keanekaragam spesies Hymenoptera parasitoid lebih tinggi di lanskap Nyalindung daripada lanskap Gasol dan Salanjabe di Daerah Aliran Sungai Cianjur, Jawa Barat. Hal ini dikarenakan struktur lanskap Gasol dan Salanjabe hampir sama yaitu padi monokultur.

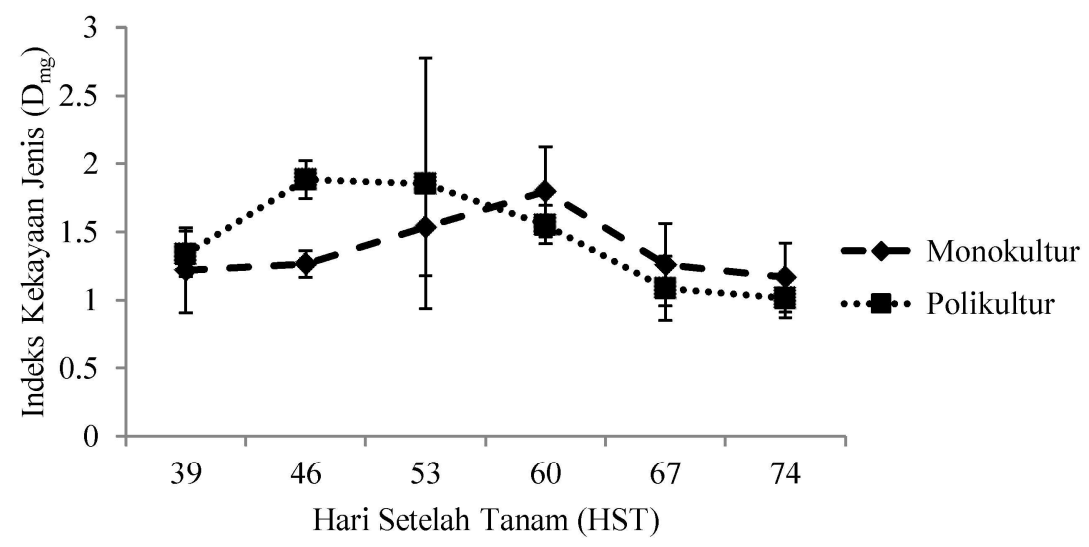

Gambar 4. Fluktuasi indeks kekayaan jenis $\left(\mathrm{D}_{\mathrm{mg}}\right)$ Arthropoda pada pertanaman tomat 


\section{KESIMPULAN}

Kemelimpahan Arthropoda pada pertanaman tomat monokultur mencapai 1.371 individu, sedangkan pada pertanaman tomat polikultur mencapai 1.188 individu. Keanekaragaman Arthropoda pada pertanaman tomat monokultur terdiri dari sembilan ordo dan 16 famili, sedangkan pada pertanaman tomat polikultur terdiri dari sembilan ordo dan 22 famili. Ratarata nilai indeks Keanekaragaman Shannon-Wiener $\left(\mathrm{H}^{\prime}\right)$; Kemerataan $(\mathrm{E})$; dan Kekayaan Jenis $\left(\mathrm{D}_{\mathrm{mg}}\right)$ Arthropoda pada sistem pertanaman tomat monokultur berturut-turut adalah 1,01;0,55; dan 1,37, sedangkan pada pertanaman tomat polikultur berturut-turut adalah 1,$16 ; 0,62 ;$ dan 1,45 .

\section{SARAN}

Karena setiap blok pertanaman dimiliki oleh setiap petani yang berbeda-beda, maka setiap blok pertanaman memiliki keadaan dan kondisi pertanaman yang beragam. Maka dari itu, disarankan untuk penelitian lebih lanjut dengan menggunakan blok pertanaman yang cenderung seragam untuk pengamatan keanekaragaman Arthropoda.

\section{DAFTAR PUSTAKA}

Badan Pusat Statistik. 2016. Produksi Nasional Sayuran. http://www.pertanian. go.id/ Data5tahun/pdf-HORTI2016/2Produksi\%20Nasional\%20Sayuran. pdf. Diakses 4 Mei 2017.

Borror, D.J., Triplehorn, C.A. \& Jonhson, N.F. 1996. Pengenalan Pelajaran Serangga Edisi ke Enam. Terjemahan S. Partosoedjono. Gadjah Mada University Press. Yogyakarta.

Edi, S. \& Julistia, B. 2010. Budidaya Tanaman Sayuran. Balai Pengkajian Teknologi Pertanian Jambi. Jambi.

Hildrew, A.G. \& Townsend, C.R. 1982. Predators and prey patchy environment a freshwater study. Jurnal Animal Ecology 51 (3): 797-815.

Indahwati, R., Budi, H. \& Munifatul, I. 2012. Keanekaragaman arthropoda tanah di lahan apel Desa Tulungrejo Kecamatan Bumiaji Kota Batu. Prosiding Seminar Nasional Pengelolaan Sumberdaya Alam dan Lingkungan. Universitas Diponegoro. Semarang.11 September 2012.
Lilies, C. 1991. Kunci Determinasi Serangga. Kanisius. Yogyakarta.

Magurran, A.E. 1988. Ecological Diversity and Its Measurement. Princeton University Press. New Jersey.

Mulyani, L. 2010. Implementasi Sistem Pertanaman Kubis: Kajian terhadap Keragaman Hama dan Musuh Alami. [Skripsi]. Universitas Sebelas Maret. Surakarta.

Mustikawati, D.R. 2012. Pengendalian Hama dan Penyakit Tanaman Sayuran. BPTP. Lampung.

Nurmaisah. 2016. Keanekaragaman Jenis dan Potensi Peran Serangga pada Lahan Pertanian Terung Belanda (Solanum betaceaum Cav.) Monokultur dan Polikultur di Desa Dieng Kulon Jawa Tengah. [Tesis]. Universitas Gadjah Mada. Yogyakarta.

Oka, I.N. 1995. Pengendalian Hama Terpadu dan Implementasinya di Indonesia. Gadjah Mada University Press. Yogyakarta.

Samudra, F.B., Munifatul, I. \& Hartuti, P. 2013. Kelimpahan dan keanekaragaman arthropoda tanah di lahan sayuran organik "urban farming". Prosiding Seminar Nasional Pengelolaan Sumberdaya Alam dan Lingkungan. Universitas Diponegoro. Semarang. 27 Agustus 2013.

Setiawati, W., Ashandi, A.A., Uhan, T.S., Warwoto, B., Somantri, A. \& Hermawan. 2005. Pengendalian kutu kebul dan nematoda parasitik secara kultur teknik pada tanaman kentang. Jurnal Hortikultura 15 (4): 288-296.

Untung, K. 1996. Pengantar Pengelolaan Hama Terpadu. Gadjah Mada University Press. Yogyakarta.

Yaherwandi. 2009. Struktur komunitas Hymenoptera parasitoid pada berbagai lanskap pertanian di Sumatra Barat. Jurnal Entomologi Indonesia $6(1): 1-14$.

Yaherwandi, Manuwoto, S., Buchori, D., Hidayat, P. \& Prasetyo, L.B. 2007. Keanekaragaman Hymenoptera parasitoid pada struktur lanskap pertanian berbeda di daerah aliran sungai (DAS) Cianjur, Jawa Barat. Jurnal Hama dan Penyaki Tumbuhan Tropika 7(1): 10-20. 
Yudha, N.A. 2016. Keanekaragaman Arthropoda pada Dua Tipe Agroekosistem Tanaman Cabai (Capsicum annum L.) di Kabupaten Tanggamus. [Skripsi]. Universitas Lampung. Lampung. 